\title{
海岸樹林による津波減災効果の評価式の構築 \\ Analysis and Evaluation of Tsunami Mitigation Effects by Coastal Vegetation
}

\author{
飯村耕介 $^{1} \cdot$ 田中規夫 ${ }^{2} \cdot$ 谷本勝利 $^{3} \cdot$ 田中茂信 ${ }^{4}$ \\ Kosuke IIMURA, Norio TANAKA, Katsutoshi TANIMOTO and Shigenobu TANAKA
}

\begin{abstract}
There are many types of coastal vegetation. However, the systematical method for evaluating the tsunami mitigation effect by coastal vegetation has not been established yet. Therefore, this study systematically analyzes the equations for tsunami through coastal vegetation and evaluates the vegetation effect on the tsunami run-up height and fluid force. The tsunami mitigation effects are investigated by numerical simulation based on non-linear long wave equations. When using $d N_{\text {all }}$, cumulative vegetation length in streamwise direction that includes the effect of different vegetation stand structures, the evaluation of the tsunami mitigation effect has been enabled. The tsunami mitigation effect and $d N_{\text {all }}$ show high correlation, and evaluation equations for tsunami mitigation effect by coastal vegetation are given by exponential functions.
\end{abstract}

\section{1.はじめに}

海岸林の津波減災効果については，特に1998年のパプ アニューギニア地震津波や 2004 年のインド洋大津波に際 して再認識され，熱帯の開発途上国における有力な津波 対策の一つとして注目されている. そのため，これまで に多様な樹種の海岸樹に対して津波減災効果が検討され ている、たとえば，平石ら（2001）や平石・岩瀬（2003） は1998年のパプアニューギニア地震津波を調査し, マン ゴーやココナッッの植林によるグリーンベルトの構築に より津波力を軽減する構想を提案し，それを評価するた めの実験や数值計算を行っている.2004年のインド洋大 津波に際しても数多くの現地調查が行われ（田中ら， 2005 ; 田中ら，2006；原田ら，2006；柳澤ら，2006）, 熱帯性海岸樹による津波の軽減を対象とした多くの研究 が行われている（谷本ら，2007；柳澤ら，2008）。しか し，多様な樹種を統一的に評価できる手法は未だ確立さ れていない. そのため, 本研究では, 海岸樹林帯をモデ ル化した実験を行い，樹木の抵抗項を取り入れた数值計 算法の検証を行う。また，その数值モデルを用いて樹種， 樹林帯幅, 津波の高さ, 陸上勾配を変化させて計算を行 い，樹林による津波の低減効果を統一的に評価できる手 法について検討を行うことを目的とする.

\section{2. 実験概要}

実験は幅 $40 \mathrm{~cm}$ の造波水路に前方部の勾配が $1 / 4.7$, 後

$\begin{array}{lll}1 & \text { 学生会員 } & \text { 修 }(\text { 工 } \\ 2 & \text { 正会員 } & \text { 工博 } \\ 3 & \text { フェロー } & \text { 工博 } \\ 4 & \text { 正会員 } & \text { 工修 }\end{array}$
埼玉大学大学院理工学研究科理工学専攻 埼玉大学教授大学院理工学研究科 埼玉大学名誉教授 (独法) 土木研究所 水災害・リスクマネ ジメント国際センター 国際普及チーム 上席研究員
方部の勾配が $1 / 20.5$ の木製の 2 段階斜面模型を設置して 行った。この水路にマングローブ林に相当する樹林模型 を設置して実験を行う（図-1）。樹林模型は直径 $5 \mathrm{~mm}$ の 木製円柱を中心間隔 $23 \mathrm{~mm}$ で千鳥状に配置（図-2）し, このときの樹林密度は 0.22 本 $/ \mathrm{cm}^{2}$ となる. 波は周期 $20 \mathrm{~s}$ の長周期波で, 図-1に示した G1 から G6の測点で容量式 波高計により水位を測定している.

\section{3. 数値計算の方法と計算条件}

\section{（1）基礎方程式}

計算に用いる基礎方程式は式（1），(2）に示す水深積 分型の1次元非線形長波方程式である.

$$
\begin{aligned}
& \frac{\partial \zeta}{\partial t}+\frac{\partial Q}{\partial x}=0 \\
& \frac{\partial Q}{\partial t}+\frac{\partial}{\partial x}\left(\frac{Q^{2}}{d}\right)+g d \frac{\partial \zeta}{\partial x}+\frac{\tau_{b}}{\rho}+\frac{F}{\rho}=0
\end{aligned}
$$

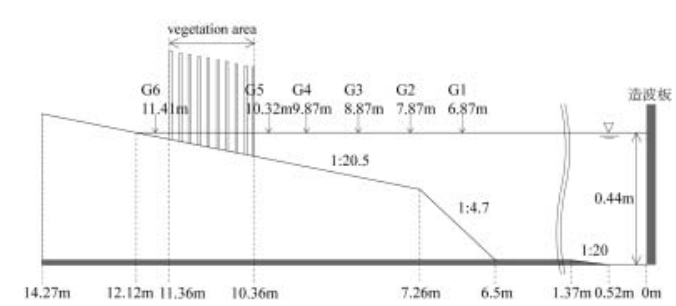

図-1 実験水路模型と測定点

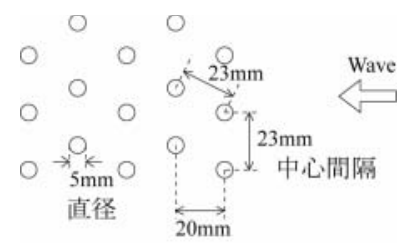

図-2 樹林模型の配置方法 
ここに, $x$ は水平座標, $t$ は時間, $\zeta$ は水位, $Q$ は線流量, $d$ は全水深 $(=\zeta+h, h$ : 静水深 $), g$ は重力加速度, $\rho$ は水 の密度， $\tau_{b}$ は底面摩擦応力， $F$ は単位面積あたりの樹木 による抵抗力である．底面摩擦応力はマニングの粗度係 数を用いて評価し，式（3）で与え，樹木による抵抗力 は式（4）で与える.

$$
\begin{gathered}
\tau_{b}=\frac{\rho g n^{2}}{d^{7 / 3}} Q|Q| \ldots \ldots . . . \\
F=\frac{1}{2} \rho \gamma C_{D-a l l} b_{\text {ref }} \frac{Q|Q|}{d}
\end{gathered}
$$

ここに, $n$ はマニングの粗度係数, $\gamma$ は樹林密度（単位 面積あたりの樹木本数)， $b_{r e f}$ は樹木の基準投影幅（胸高 での幹の直径で与える）であり， $C_{D-\text { all }}$ は式 (5) で与え る樹木の抵抗係数である（田中・佐々木，2007）.

$$
C_{D-\text { all }}(d)=C_{D-\text { ref }} \frac{1}{d} \int_{0}^{d} \frac{b(z)}{b_{\text {ref }}} \frac{C_{D}(z)}{C_{D-\text { ref }}} d z
$$

ここに, $C_{D-\text { ref }}$ は基準抵抗係数（胸高での幹に対する抗 力係数で与える), $b$ および $C_{D}$ は地面からの高さ $z$ での幹 と枝の投影幅书よびそこでの樹木の抗力係数である。こ のように, $C_{D \text {-all }}$ は高さ方向における抗力係数の変化と投 影幅の変化を含み，全水深（没水深）の関数である. 本 研究で対象とした樹木は，熱帯に扔ける海岸樹として， 砂丘上に生育するアダン (Pandanus odoratissimus)，モク マオウ (Casuarina equisentifolia)，カシューナッッ (Anacardium occidentale) と潮汐の干満帯に生育するフ夕 バナヒルギ (Rhizophora apiculata) の4種である (写真-1). 表-1に田中ら（2005，2006，2007）の現地調查結果に基 づいた樹木の平均的な諸元，図-3に各樹木の抵抗特性 $\left(C_{D-a l l}\right.$, 谷本ら，2007）を示す。表および図中の $H_{\text {Tree }}$ は 樹高であり，樹林密度 $\gamma$ は各樹木の樹間距離で正三角形 （千鳥状）配置した場合の単位面積あたりの樹木本数で ある. $C_{D-\text { all }}$ の值や分布は樹木によって異なり，気根を有 し，投影幅の大きいアダンやフタバナヒルギが大きな值 を示している．数值計算は基礎式を差分式に変換して行 う. 差分化の方法等は谷本ほか（2007）に従って行う.

\section{(2) 計算条件}

計算は現地スケールで，樹種，樹林带幅，津波高さ， 陸上の地形勾配を変化させて行う．図-4に対象とした海 岸地形と樹林帯の配置方法を示す。基準面上 $+0.0 \mathrm{~m}$ まで は1/100勾配で，陸上の地形勾配 $i_{L}$ は $1 / 100 ， 1 / 150 ， 1 / 200$, $1 / 250 ， 1 / 500 ， 1 / 1000$ の 6 ケースについて検討する。図中 の樹林帯(1)には潮汐の干満帯に生育するフタバナヒル ギ，樹林帯(2)には砂丘上に生育するアダン，モクマオウ， カシューナッッを配置し, 樹林带幅 $W_{v}$ は $10 \mathrm{~m}, 20 \mathrm{~m}$, $50 \mathrm{~m} ， 100 \mathrm{~m} ， 200 \mathrm{~m}$ の 5 ケースとする．また，来襲する津 波は周期 20 分で，汀線での津波高さ $H_{s l}$ が $3 \mathrm{~m} ， 5 \mathrm{~m} ， 7 \mathrm{~m}$

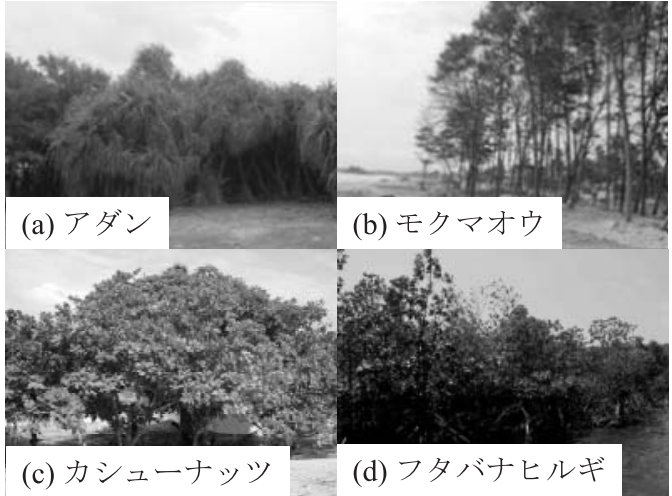

写真-1 対象とする熱帯性海岸樹

表-1＼cjkstart樹木の諸元

\begin{tabular}{l|c|c|c|c}
\hline \multirow{2}{*}{ 樹木名 } & $H_{\text {Tree }}$ & $b_{\text {ref }}$ & 樹間距離 & $\gamma$ \\
\cline { 2 - 5 } & $(\mathrm{m})$ & $(\mathrm{m})$ & $(\mathrm{m})$ & $\left(\mathrm{C} / \mathrm{m}^{2}\right)$ \\
\hline アダン & 6 & 0.155 & 1.692 & 0.403 \\
\hline モクマオウ & 10 & 0.124 & 2.160 & 0.247 \\
\hline カシューナッツ & 5 & 0.297 & 7.100 & 0.023 \\
\hline フタバナヒルギ & 8 & 0.177 & 3.336 & 0.104 \\
\hline
\end{tabular}

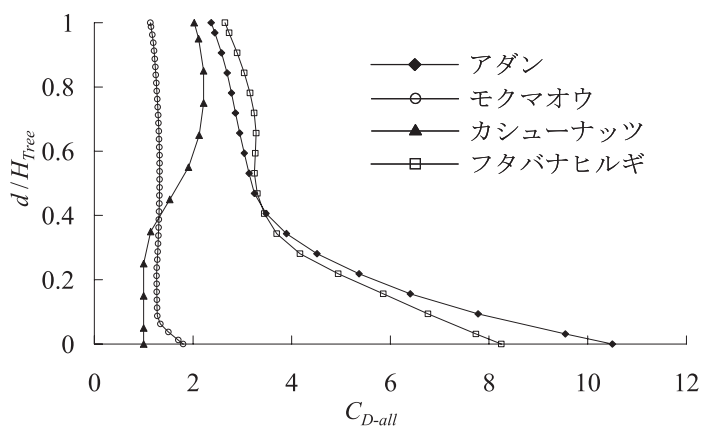

図-3 各樹木の抵抗特性

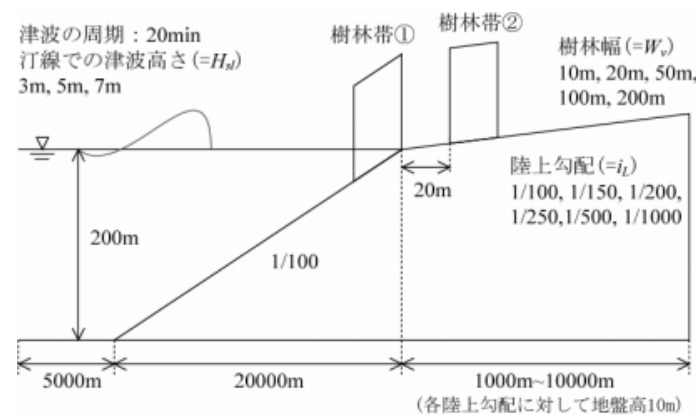

図-4 海岸地形と樹林帯の配置方法

の3ケースについて検討する。な押，これらは特定の地 点を対象としたものではなく，一つのモデルとして想定 したものである. 


\section{4. 結果と考察}

（1）実験結果と数值モデルの検証

実験は，多重反射系水路においてほぼ定常状態になる まで待って測定する手法で行っている，そのため，入射 波高は樹林模型が無い状態で，測点 G1での実験および 数值計算による波高が一致するように定めた，その結果， 造波水深 $0.44 \mathrm{~m}$ での入射波高は $0.019 \mathrm{~m}$ となった。なお， 数值計算における格子間隔は $0.01 \mathrm{~m}$, 時間間隔は $0.0024 \mathrm{~s}$ であり，マニングの粗度係数 $n$ は比較的粗い木製床に対 し 0.012 としている. また, 樹林模型の抗力係数 $C_{D-r e f}$ を 1.5 としている.この条件で実験と数值計算の比較を行う. 図-5に波高分布の実験および数值計算結果を示す。横軸 は造波板からの距離 $x$, 縦軸は波高 $H$ である. 数值計算 結果の方が実験結果よりやや大きくなるものの，樹林模 型の有無による波高の変化を良く表現している．樹林模 型を設置することにより，模型背後（G6）では波高が大 きく低減する．測点 $\mathrm{G} 6$ において模型がない場合の波高 が $0.063 \mathrm{~m}$ なのに対して，模型を設置した場合の波高は $0.042 \mathrm{~m}$ となり，約 3 割程度波高を低減する。なお， $x$ が $11.3 \mathrm{~m}$ 以上の数值計算結果において波高が急激に低下す るが，これは引き波の際に底面が露出し，最低水位が底 面の高さに一致するためである。図-6，7にそれぞれ模 型なし，ありにおける測点 G6での水位の時間変化を示 す. 両図から，水位の時間変化についても数值計算結果 は実験結果を良く再現していることが分かる。したがっ て, この数值計算モデルを用いて現地スケールでの計算 を行う。

\section{(2) 現地スケールでの数値計算}

3.（2）で示した条件で数值計算を行い，樹林帯による 津波の低減効果について検討する。まず，図-8に各ケー スにおける樹林帯がない条件での遡上高 $R_{0}$ を示す．横軸 は陸上勾配 $i_{L}$ で, 汀線での津波高さ $H_{s l}$ が大きくなるほど 遡上高も大きくなる．図-9に $i_{L}=1 / 1000$ における無次元遡 上高（樹林帯有り条件での遡上高 $R /$ 樹林帯無し条件で の遡上高 $R_{0}$ ）の樹林帯幅 $W_{v}$ による変化を示す. 図には 1 つの $W_{v}$ に対して 4 樹種と津波高さ3ケースについて示し ている。谷本ら（2007）でも指摘されているとおり，樹 林帯幅を大きくするほど遡上高は低減されるが，その程 度は樹種によって異なり, 気根を有し, 密生するアダン の抵抗が最も大きくなる. 樹種による効果の差が大きく, この図から一つの評価式を得るのは非常に困難である. そこで，横軸を樹林帯幅 $W_{v}$ ではなく，樹林帯の厚みを表 すパラメータとして $d N_{\text {all }}$ を定義し，これを用いて樹林帯 による低減効果を整理する。首藤（1985）は樹林の厚み として $d n$ を用いた。これは汀線沿いに単位長をもち，樹 林带幅 $W_{v}$ を他の一辺とする長方形内に存在する樹木の総

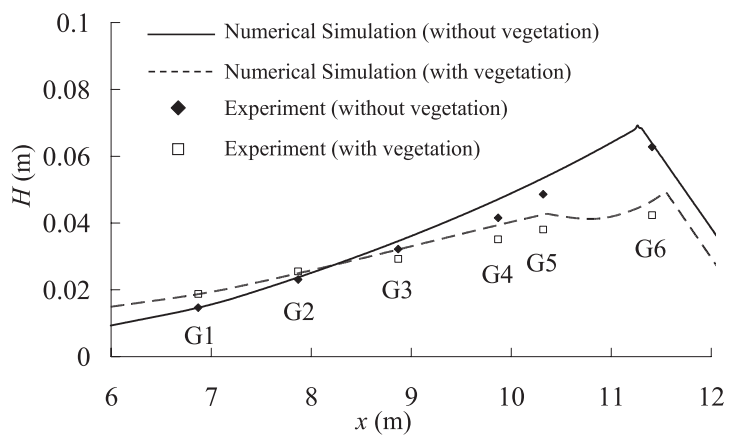

図-5 波高分布

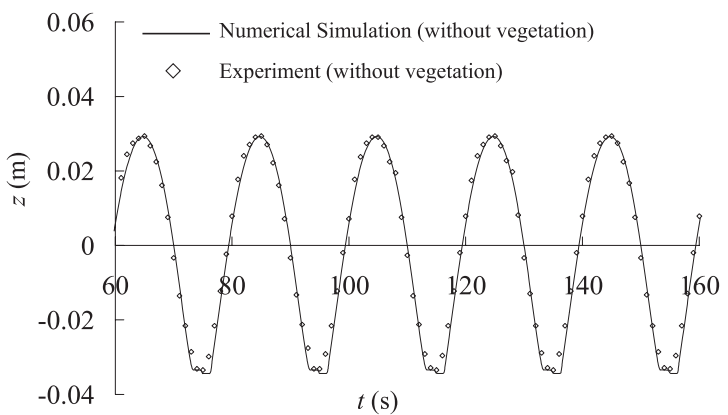

図-6 測点G6における水位の時間変化（樹林なし）

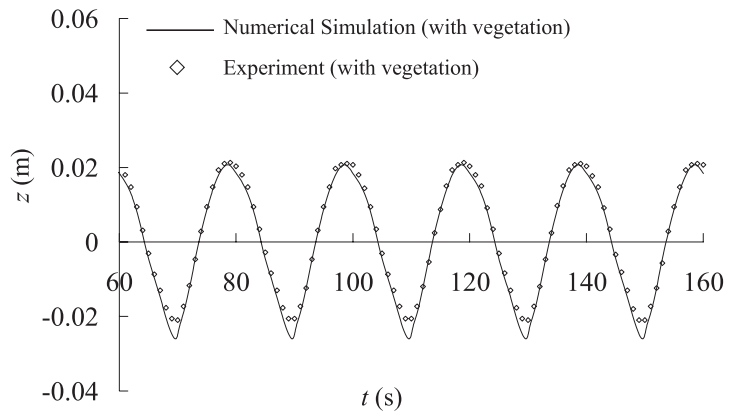

図-7 測点G6における水位の時間変化（樹林あり）

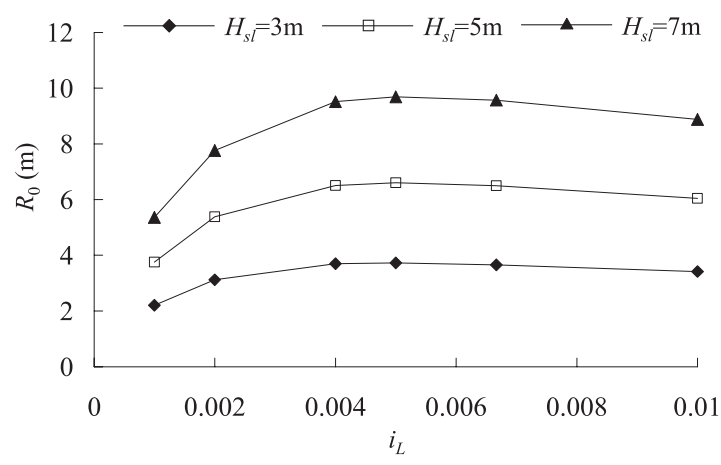

図-8＼cjkstart樹林帯がない条件での遡上高 $\mathrm{R}_{0}$ 
本数と樹木の胸高直径 $b_{r e f}$ との積で与えられる量であり, 式（6）で与えられ，単位は（本・ $\mathrm{cm} ）$ となる.

$$
d n=\gamma\left(1 \times W_{v}\right) b_{r e f} \times 100
$$

なお， $d n$ を算出する際に用いる胸高直径の単位には $\mathrm{cm}$ を用いるため，式（6）では単位をあわせるために 100 をかけている. 図-10に $i_{L}=1 / 1000$ における無次元遡上 高の $d n$ による変化を示す。図-9に比べて結果はまとまっ

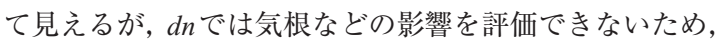
気根の有無により差が見られる。そこで，樹種による抵 抗特性の違いを考慮できるように, $d N_{\text {all }}$ を式（7）で与 える（田中ら，2005）。

$$
d N_{\text {all }}=d n \times C_{D-\text { all }}
$$

$C_{D-\text { all }}$ は樹木の抵抗特性值で個々の樹木の投影幅の鉛直 分布や葉層の影響を考慮したものであるが，全水深の関 数であるため時間や場所によって值が変化してしまう. したがって， $d N_{\text {all }}$ を算出する際には，代表值としてアダ ン，モクマオウ，カシューナッツの場合は全水深 $d$ に樹 林帯がない場合の汀線での津波高さ $H_{s l}$ を, フタバナヒル ギの場合は全水深 $d$ に樹林帯がない場合の汀線での津波 高さ $H_{s l}$ と樹林帯前面での静水深 $h$ 和をそれぞれ代入し て求めることとした。図-11に $i_{L}=1 / 1000$ における無次元 遡上高の $d N_{\text {all }}$ による変化を示す． $d N_{\text {all }}$ を用いることで無 次元遡上高の変化を, 樹種によらず一様に評価できてい

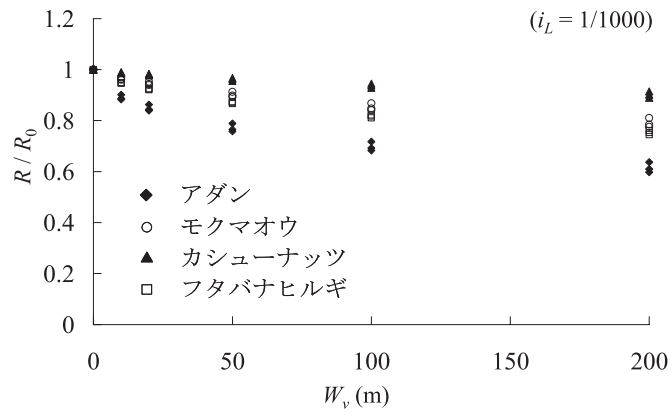

図-9＼cjkstart無次元遡上高の $W_{v}$ による变化 $\left(i_{L}=1 / 1000\right)$

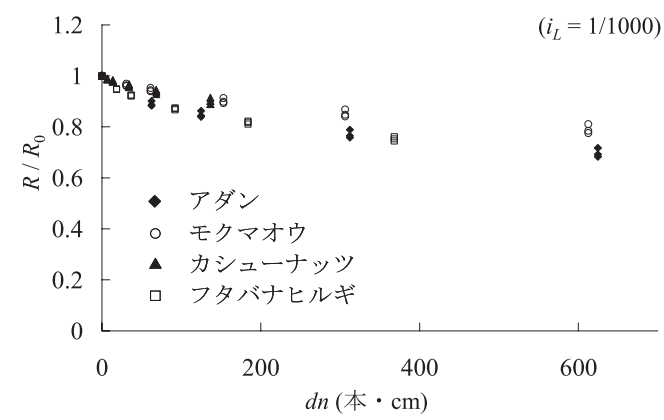

図-10 無次元遡上高の $d n$ による変化 $\left(i_{L}=1 / 1000\right)$
ることが分かる，また，図中には近似曲線も示している. 近似曲線を式（8）に示す形で与えると， $i_{L}=1 / 1000$ の場 合, 係数 $\alpha=0.00828$, 決定係数 $\mathrm{R}^{2}=0.941$ となり, $d N_{\text {all }}$ と 無次元遡上高との間に高い相関があることが分かる.

$$
R / R_{0}=e^{-\alpha \sqrt{d N_{a l l}}}
$$

同様にして，ほかの陸上勾配についても無次元遡上高 を $d N_{\text {all }}$ で評価し, 近似曲線を求める。図-12に $d N_{\text {all }}$ を用 いたときの各陸上勾配における無次元遡上高の近似曲線 を示す。遡上高の軽減効果は陸上の地形勾配が緩くなる ほど大きくなり， $d N_{\text {all }}$ が 1000 のと， $i_{L}=1 / 100$ では遡上 高の低減率（1- 無次元遡上高）が 0.11 なのに対して, $i_{L}=1 / 200$ での低減率は $0.18, i_{L}=1 / 1000$ での低減率は 0.23 にもなる．表-2には各陸上勾配における近似曲線の係数 $\alpha$ と決定係数 $\mathrm{R}^{2}$ と示しており，陸上勾配が緩くなるほど 相関が高くなる。

遡上高と同じょうに流体力についても検討する．流体 力 $F^{*}$ は式 $(4)$ を変形して次式で定義する（谷本ほか, 2007).

$$
F^{*}=\frac{F}{\gamma C_{D-a l l} b_{r e f}}=\frac{1}{2} \rho \frac{Q|Q|}{d}
$$

これは抗力係数が 1 の高さ方向に一様な物体が受ける 単位幅当たりの抗力に相当する。また，流体力は汀線か ら陸側に $300 \mathrm{~m}$ 離れた地点での值を用いて検討する。図13 に樹林帯がない条件での流体力 $F_{0}{ }_{0}$ を示す．流体力は

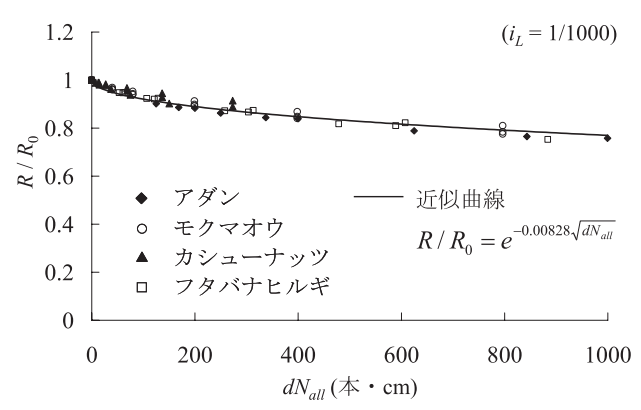

図-11＼cjkstart無次元遡上高の $d N_{\text {all }}$ による変化 $\left(i_{L}=1 / 1000\right)$

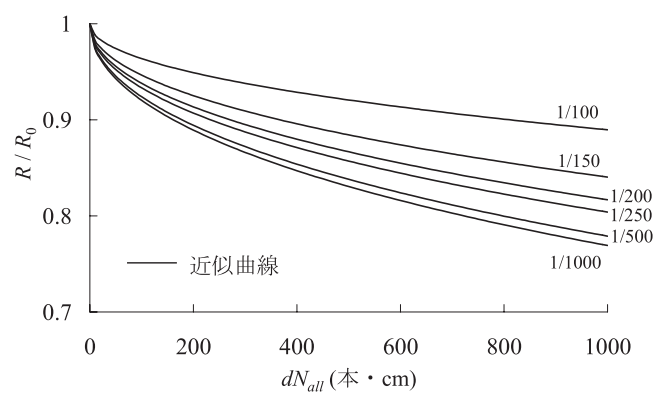

図-12 各陸上勾配における無次元遡上高の近似曲線 
表-2 各陸上勾配における係数 $\alpha$ と決定係数 $\mathrm{R}^{2}$ (遡上高)

\begin{tabular}{c|c|c}
\hline 陸上勾配 $i_{L}$ & 係数 $\alpha$ & 決定係数 $\mathrm{R}^{2}$ \\
\hline $1 / 100$ & 0.00371 & 0.673 \\
\hline $1 / 150$ & 0.00546 & 0.798 \\
\hline $1 / 200$ & 0.00637 & 0.850 \\
\hline $1 / 250$ & 0.00691 & 0.877 \\
\hline $1 / 500$ & 0.00787 & 0.923 \\
\hline $1 / 1000$ & 0.00828 & 0.941 \\
\hline
\end{tabular}

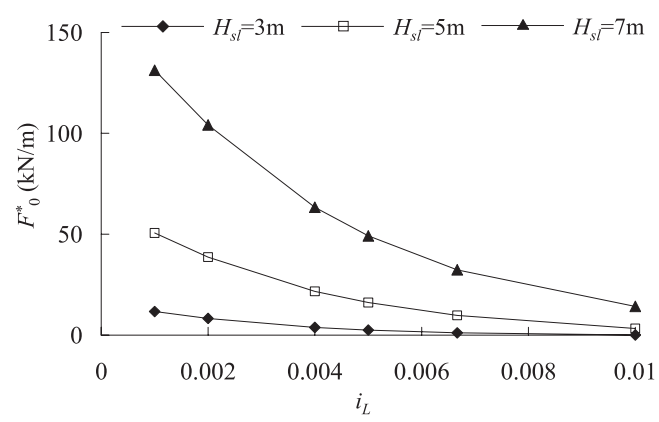

図-13 樹林帯がない条件での流体力 $F_{0}^{*}$

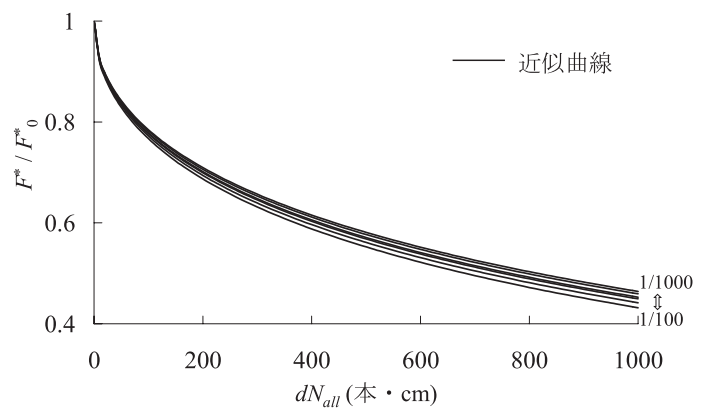

図-14各陸上勾配における無次元流体力の近似曲線

表-3 各陸上勾配における係数 $\alpha$ と決定係数 $\mathrm{R}^{2}$ (流体力)

\begin{tabular}{c|c|c}
\hline 陸上勾配 $i_{L}$ & 係数 $\alpha$ & 決定係数 $\mathrm{R}^{2}$ \\
\hline $1 / 100$ & 0.02655 & 0.905 \\
\hline $1 / 150$ & 0.02584 & 0.902 \\
\hline $1 / 200$ & 0.02529 & 0.924 \\
\hline $1 / 250$ & 0.02507 & 0.936 \\
\hline $1 / 500$ & 0.02460 & 0.954 \\
\hline $1 / 1000$ & 0.02428 & 0.960 \\
\hline
\end{tabular}

汀線での津波高さが大きいほど，また陸上勾配が緩いほ ど大きくなる傾向にある。図-14に $d N_{\text {all }}$ を用いたときの 各陸上勾配における無次元流体力（樹林帯有り条件での 流体力 $F^{*}$ /樹林带無し条件での流体力 $F_{0}^{*}$ ) の近似曲線を 示す. 無次元流体力の近似曲線は無次元遡上高のときと 同じように式（8）の形で与える. 流体力の低減率は遡 上高に比べて全体的に大きく，また陸上勾配による低減 率の差があまりない. 表-3には各陸上勾配における無次
元流体力の近似曲線の係数 $\alpha$ と決定係数 $\mathrm{R}^{2}$ と示してお り，陸上勾配によらず高い相関を示している。

このように，樹種によらずに津波軽減効果の評価を可 能にした。この評価式 (近似曲線) を用いれば, 本研究 で対象としなかった樹種に対しても, 樹木の諸元や樹林 帯幅, 投影幅の鉛直分布などが分かれば数值計算を行わ なくとも $d N_{\text {all }}$ から津波の減衰率を得ることができる.

\section{5. おわりに}

本研究では，樹林帯による津波の軽減効果について統 一的に評価できる手法について検討を行った。海岸樹林 帯による津波遡上高および流体力の軽減効果については $d N_{\text {all }}$ を用いることで樹種によらず指数関数を用いた近似 式で一様に評価できるようになった。遡上高の軽減効果 は陸上勾配が緩くなるほど効果が大きく, また $d N_{\text {all }}$ と遡 上高の減衰率との間の相関が高くなる。一方, 流体力の 軽減効果については陸上勾配による差はあまり生じな い. 今後は模型実験により $d N_{\text {all }}$ の検証を行う予定である. また, 本研究では樹木の破壊を考慮していないため, 津波 外力が大きいほど減災効果を過大評価している可能性があ る. 今後, 樹木の破壞を考慮した検討が必要である.

\section{参 考 文 献}

首藤伸夫（1985）：防潮林の津波に対する効果と限界，第32 回海岸工学講演会論文集, pp. 465-469.

田中規夫 · 佐々木寧 · 湯谷賢太郎 - Samang Homchuen （2005）：津波防御に対する樹林帯幅と樹種の影響につい てーインド洋大津波における夕イでの痕跡調査一, 海岸 工学論文集，第52巻，pp.1346-1350.

田中規夫・武村 武・佐々木寧・M.I.M. Mowjood（2006）：ス リランカ海岸林の樹種による破壊条件と津波到達遅延時 間の相違, 海岸工学論文集, 第53巻, pp.281-285.

田中規夫・佐々木寧（2007）：2006年ジャワ津波災害におい て海岸林が果たした役割とその破断・なぎ倒し限界，水 工学論文集, 第51巻, pp.1445-1450.

谷本勝利 - 田中規夫 - N.A.K. Nandasena - 飯村耕介 - 清水 隆 （2007）：種々の熱帯性海岸樹の組合せによる津波防御効 果に関する数值計算, 海岸工学論文集, 第 54 巻, pp.13811385.

原田賢治・沖村 孝・鳥居宣之（2006）：インド南東部にお けるスマトラ地震津波の被災調査, 海岸工学論文集, 第 53 卷, pp.296-300.

平石哲也・竹村慎治・永瀬恭一（2001）：南太平洋地域にお ける植林による津波対策法の適用性, 海岸工学論文集, 第 48 巻, pp.1411-1415.

平石哲也・岩瀬浩之（2003）：1998年パプアニューギニア津 波を対象としたグリーンベルト防災の効果，海岸工学論 文集，第50巻，pp.1366-1370.

柳澤英明・越村俊一・後藤和久 · 今村文彦・宮城豊彦・林 一 （2006）：マングローブ林内を遡上した津波の挙動と樹木の 破壞条件 - 2004年インド洋大津波による夕イKhao Lakで の被害調査 - , 海岸工学論文集, 第 53巻, pp.231-235.

柳澤英明・越村俊一・宮城豊彦・今村文彦（2008）：2004年 インド洋大津波におけるマングローブ林のフラジリティー 関数と津波減衰効果, 海岸工学論文集, 第 55 巻, pp.286290. 